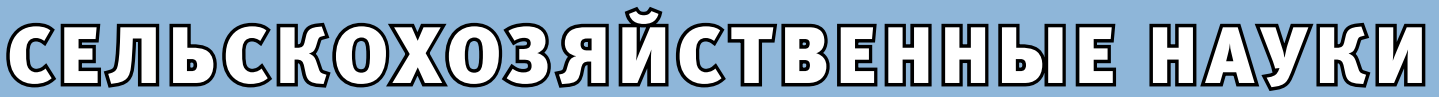

DOI

УдК 575.174.015.3+636.034

\section{ОЦЕНКА ПОЛИМОРФИЗМА СЗ37G ГЕНА FSHR В ПОПУЛЯЦИИ ЧЕРНО-ПЕСТРОГО ГОЛШТИНИЗИРОВАННОГО СКОТА}

\author{
БАБИЙ Анна Владимировна, ФГБНУ «Центр экспериментальной эмбриологии и репродуктивных \\ биотехнологий»
}

АРХИПОВА Анна Леонидовна, ФГБНУ «Центр экспериментальной эмбриологии и репродуктивных биотехнологий»

БУРСАКОВ Сергей Алексеевич, ФГБНУ «Центр экспериментальной эмбриологии и репродуктивныхх биотехнологий»

БРИГИДА Артем Владимирович, ФГБНУ «Центр экспериментальной эмбриологии и репродуктивных биотехнологий»

кЛИМОВ Евгений Александрович, ФГБНУ «Центр экспериментальной эмбриологии и репродуктивных биотехнологий»

коВАЛЬЧУК Светлана Николаевна, ФГБНУ «Центр экспериментальной эмбриологии и репродуктивных биотехнологий»

Одним из ключевых этапов технологии ускоренного воспроизводства крупного рогатого скота является отбор коров-доноров, наиболее чувствительных к процедуре гормональной стимуляции овуляции. К настоящему времени одним из перспективных генетииеских маркеров репродуктивного статуса крупного рогатого скота является ген рецептора фолликулостимулирующего гормона (FSHR). Особое внимание привлекает SNP C337G (rs43745234), ассоциированный с количеством оплодотворенных ооцитов и жизнеспособных эмбрионов. Целью данной работы была оценка полиморфизма C337G гена FSHR в популящии черно-пестрого голитинизированного скота. В статье представлены данные по генотипированию 190 коров иерно-пестрого голитинизированного скота по аллельным вариантам G337C гена FSHR (rs43745234) методом ПЦР-ПДРФ. Анализ полученных результатов показал, ито в исследованной популяции крупного рогатого скота частоты аллелей $C$ и G составляли 0,7 и 0,3. Частоты генотипов $C / C$ и $C / G$ были 0,474 и 0,453. Частота генотипа $G / G$, ассоциированного по литературным данным с большим количеством жизнеспособных эмбрионов, составила лишъ 0,074 .

Введение. На сегодняшний день технология трансплантации эмбрионов зарекомендовала себя в качестве надежного метода ускоренного воспроизводства и генетического улучшения сельскохозяйственных видов животных. Для крупного рогатого скота технологии воспроизводства наиболее перспективных особей с точки зрения их генетического потенциала были разработаны на основе стратегического использования элитных коров-доноров в программах по стимуляции суперовуляции и переноса эмбрионов [10].

Одной из актуальных задач в области биотехнологии воспроизводства крупного рогатого скота является отбор по генетическим показателям коров-доноров, наиболее чувствительных к процедуре гормональной стимуляции овуляции и способных произвести в результате максимальное количество зрелых ооцитов [3].

Среди потенциальных генов-кандидатов, широко изучаемых в контексте феномена суперовуляции у крупного рогатого скота, числятся гены ряда гормонов, включая ФСГ $[1,5,19]$. ФСГ (фолликулостимулирующий гормон) вместе с другими гонадотропными гормонами гипофиза обеспечивает нормальную репродуктивную функцию за счет своей основной роли в процессе формирования половых клеток: у самцов ФСГ инициирует и поддерживает сперматогенез, у самок данный гормон отвечает за развитие и созревание фолликулов в яичниках $[11,18]$. Физиологический эффект ФСГ обеспечивается за счет взаимодействия с рецептором, экспрессируемым гранулезными клетками [8]. К настоящему времени ген рецептора ФСГ (FSHR) является первым и наиболее изученным генетическим фактором, связанным с суперовуляцией у крупного рогатого скота [1]. FSHR принадлежит к классу мембранных рецепторов, связанных c G-белками, чья активация запускает сигнальный путь циклического аденозинмонофосфата (цАМФ) [13]. В геноме Bos taurus ген FSHR локализован на хромосоме 11 и состоит из 10 экзонов. Первые 9 экзонов кодируют внеклеточный домен рецептора, экзон 10 кодирует трансмембранный домен [11].

В литературе накоплены данные о связи точечных мутаций в гене FSHR (SNP, single nucleotide polymorphism) с суперовуляторным ответом настимуляцию гонадотропинами. В гене FSHR B. taurus SNP выявлены в 5-'UTR и кодирующей частях методом SSCP (SingleStrand Conformation Polymorphism) и исследованы на предмет возможных ассоциаций с репродуктивным потенциалом у крупного рогатого скота голштинской породы $[5,15,20]$. Особый интерес вызывают несинонимичные замены в экзонах, поскольку такого рода изменения в первичной структуре гена влияют на последовательность и конформацию соответствующего белка. Изучение кодирующей части гена FSHR на предмет выявления SNP выявило 3 несинонимичные мутации C337G, A871G, C1973G, соответствующие белковым заменам P113A, I291V, T658S [5, 15]. Эффект данных генотипов оценивали с учетом нескольких параметров: общее количество полученных ооцитов и эмбрионов (ОКОЭ), процент жизнеспособных эмбрионов (ПЖЭ), процент дегенерированных эмбрионов (ПДЭ), процент неоплодотворенных ооцитов (ПНО).

В данном контексте особое внимание привлекает SNP C337G (rs43745234). Было выявлено, что особи, го- 
мозиготные по аллелю G (генотип GG) характеризуются более высоким показателем ПЖЭ; животные с генотипами GG и гетерозиготы (генотип CG) имеют меньше неоплодотворенных ооцитов по сравнению с коровами, гомозиготными по аллелю С (генотип СС) [5]. Мутация C337G в экзоне 4 гена FSHR приводит к замене аминокислотного остатка пролина на аланин во внеклеточном лиганд-связывающем домене белка FSHR. Известно, что остатки пролина играют важную структурную и функциональную роль в мембранных белках и участвуют в поддержании стабильности белка $[12,17]$. Следует ожидать, что замена P113А влияет на стабильность FSHR и на взаимодействия ФСГ с рецептором [9].

На сегодняшний день одним из наиболее широко применяемых методов для выявления SNP является ПЦР-ПДРФ (полимеразная цепная реакция - полиморфизм длин рестрикционных фрагментов) [2].

Цель данной работы - оценка полиморфизма C337G (rs43745234) гена FSHR в популяции черно-пестрого голштинизированного скота методом ПЦР-ПДРФ.

Методика исследований. Исследовали 190 коров черно-пестрого голштинизированного скотаживотноводческого хозяйства Калужской области. ДНК выделяли из образцов цельной крови коров с использованием набора $M$-Сорб (Синтол, Россия).

Специфичные праймеры разрабатывались на основе последовательности гена FSHR B. taurus (Gene ID 281172 ) с учетом локализации однонуклеотидной замены C337G в экзоне 4 (rs43745234). Для конструирования праймеров и подбора эндонуклеазы использовалась программа GeneRunner [7]. Реакционная смесь для ПЦР (общий объем 20 мкл) готовилась с использованием набора HS TaqDNA Polymerased NTP mix (Евроген, Россия), праймеров 5'-GCTAAACTAAAACCCACCAG-3' и 5'-TGCTTTGTTTGTCTCTGATGA-3' (конечная концентрация 0,2мкМ каждого) и 10 нг ДНК. Реакцию амплификации проводили в следующих условиях: 3 мин при $95{ }^{\circ} \mathrm{C}$ (1 цикл); 15 с при $95^{\circ} \mathrm{C}, 15$ с при $58{ }^{\circ} \mathrm{C}, 15$ с при $72^{\circ} \mathrm{C}$ (40 циклов).

Рестрикционный анализ проводили в 20 мкл смеси, содержащей полученные ампликоны, 2 мкл буфеpa G (10×) и 0,5 мкл эндонуклеазы HgaI (СибЭнзим, Россия)в течении 16 ч при $37^{\circ} \mathrm{C}$.

Результаты ПЦР-ПДРФ оценивали методом электрофореза в 1,2\%-м агарозном геле. Расчет частот встречаемости выявленных генотипов и алеллей проводился методом прямого подсчета, используя формулу

$$
P(A)=\frac{\left(2 N_{1}+N_{2}\right)}{2 n},
$$

где $N_{1}$ - число гомозигот по исследуемому аллелю; $\mathrm{N}_{2}$ - число гетерозигот; $n$ - объем выборки.

Статистическую ошибку частот аллелей генов вычисляли по формуле:

$$
S(p)=\sqrt{\frac{p q}{n}},
$$

где $p$ - частота исследуемого аллеля; $q=1$ - $p ; n$ - объем выборки.

Для оценки отклонения наблюдаемых генотипов от равновесия Харди-Вайнберга (избыток гетерозигот) использовалось значение $\chi^{2}$ :

$$
\chi^{2}=\sum \frac{\left(H_{o}-H_{e}\right)^{2}}{H_{e}},
$$

где $H_{o}$ - наблюдаемая гетерозиготность; $H_{e}$ - ожидаемая гетерозиготность.
Для определения функционального эффекта аминокислотной замены P113А в белке рецептора фолликулостимулирующего гормона использовался онлайн сервис PROVEAN (http://provean.jcvi.org/index.php) [4].

Результаты исследований. С помощью методики стимуляции суперовуляции в мире ежегодно получают более 500000 эмбрионов крупного рогатого скота [14]. Несмотря на то, что в последние десятилетия в технологию трансплантации эмбрионов были внедрены новые высокотехнологичные методы, эффективность процедуры стимуляции суперовуляции у коров-доноров существенно не увеличилась. Одним из основных лимитирующих факторов развития технологии является высокая вариабельность ответа со стороны организма коров-доноров на гормональную обработку. Физиологический эффект обработки коров-доноров гонадотропинами по-прежнему остается индивидуальным и непредсказуемым [16]. Вместе с тем исследования показали, что эффективность стимуляции овуляции тесно связана с аллельными вариантами гена FSHR $[5,6]$. Таким образом, ген FSHR является перспективным геном-кандидатом для исследования эффекта точечных мутаций на способность коров-доноров к суперовуляции.

В данной работе было выполнено генотипирование черно-пестрого голштинизированного скота методом ПЦР-ПДРФ и дан анализ частот аллелей G337C гена FSHR (rs43745234). Для определения генотипа каждого из исследованных животных амплифицированные в ходе ПЦР фрагменты гена FSHR длиной 475 п.н. были обработаны эндонуклеазой HgaI с последующим электрофоретическим разделением полученных фрагментов ДНК. По результатам электрофореза были выявлены носители всех трех генотипов FSHR (см. рисунок).

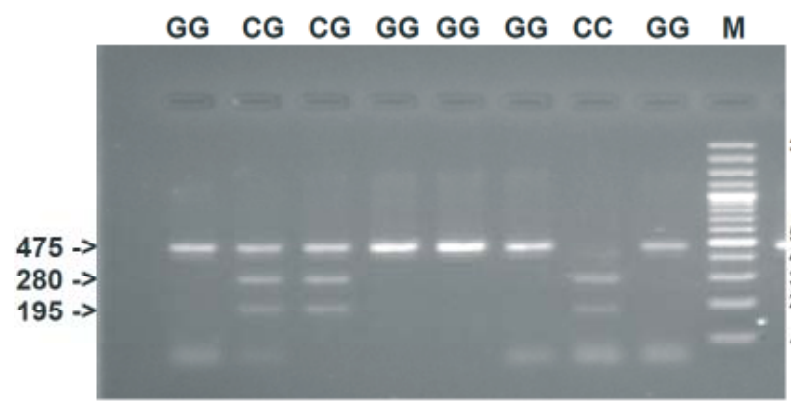

Пример электрофоретического разделения продуктов рестрикции при генотипировании КРС по аллельным вариантам C337G гена FSHR методом ПЦР-ПДРФ. Представлены гетерозиготный (CG) и гомозиготные (GG и CC) генотипъ. М - маркер длин ДНК (100-3000 n.н., GeneRuler $^{\text {TM }} 100$ bp DNA Ladder Plus, Thermo Scientific)

Гомозиготный генотип по аллелю G (генотип GG) характеризуется наличием на электрофореграмме одного фрагмента ДНК длиной 475 пар нуклеотида (п.н.); в электрофоретическом спектре образцов, гомозиготных по аллелю С (генотип СС), определяются 2 рестрикционных фрагмента (195 и 280 п.н.); для гетерозиготных образцов (генотип CG) специфично наличие всех трех фрагментов ДНК (195, 280 и 475 п.н.).

Анализ результатов выявил следующие частоты генотипов и аллелей (см. таблицу). Распределение генотипов соответствует равновесию Харди-Вайнберга $\left(\chi^{2}=1,1469\right)$, что свидетельствует об отсутствии отбора в исследованной популяции черно-пестрого голштинизированного скота. 
Частоты генотипов и аллелей замены rs43745234 в гене FSHR

\begin{tabular}{|c|c|c|}
\hline Генотип & Количество $(n)$ & $P$ \\
\hline CC & 90 & 0,474 \\
\hline CG & 86 & 0,453 \\
\hline GG & 14 & 0,074 \\
\hline Аллель & Количество & $P \pm S(p)$ \\
\hline C & 266 & $0,700 \pm 0,033$ \\
\hline G & 114 & $0,300 \pm 0,033$ \\
\hline
\end{tabular}

$P$ - частота аллеля; $S(p)$ - стандартная ошибка.

По результатам статистической обработки (см. таблицу) и с учетом литературных данных [5] выявлено, что в опытной выборке коров преобладают аллели, ассоциированные с более высоким количеством оплодотворенных ооцитов (генотипы GG и CG) и большим количеством жизнеспособных эмбрионов (генотип GG).

Исследуемая замена C337G приводит к изменению аминокислотной последовательности белка FSHR - P113A. По данным сервиса PROVEAN, эта замена является нейтральной, т.е. не нарушает нормального функционирования белка (PROVEAN score $=2,443$, пороговое значение $-2,5$ ). Вместе с тем в экспериментах in silico было показано, что замена А113Р приводит к конформационным изменениям в молекуле FSHR, повышению ее стабильности, снижению гидрофобности и изменению аффинности к ФСГ [9]. Данные изменения способны влиять на эффективность активации сигнальных путей, регулирующих, в частности, фолликулогенез.

Заключение. Нами впервые определены частоты аллелей C337G гена FSHR и генотипов в популяции черно-пестрого голштинизированного скота методом ПЦР-ПДРФ. Выявление аллельных вариантов гена FSHR и их связи с феноменом суперовуляции у коров-доноров является одним из перспективных направлений в области репродуктивных биотехнологий крупного рогатого скота и требует дальнейших исследований.

\section{СПИСОК ЛИТЕРАТУРЫ}

1. Генетические маркеры суперовуляторного ответа у крупного рогатого скота / С.А. Бурсаков [и др.] // Проблемы биологии продуктивных животных. - 2017. № 4. - C. 5-23.

2. Berg H. Restriction Fragment Length Polymorphism Analysis of PCR-Amplified Fragments (PCR-RFLP) and Gel Electrophoresis - Valuable Tool for Genotyping and Genetic Fingerprinting // Gel Electrophoresis - Principles and Basics, In Tech, 2012.

3. Bó G.A., Mapletoft R.J. Historical perspectives and recent research on superovulation in cattle // Theriogenology, 2014, Vol. 81, P. 38-48.

4. Choi Y., Chan A.P. PROVEAN web server: A tool to predict the functional effect of amino acid substitutions and indels // Bioinformatics, 2015, Vol. 31, P. 2745-2747.

5. Cory A.T., Price C.A., Lefebvre R., Palin M.F. Identification of single nucleotide polymorphisms in the bovine follicle-stimulating hormone receptor and effects of genotypes on superovulatory response traits //Animal Genetics, 2013, Vol. 44, P. 197-201.

6. Fauser B., Diedrich K., Devroey P. Predictors of ovarian response: Progress towards individualized treatment in ovula- tion induction and ovarian stimulation // Human Reproduction Update, 2008, Vol. 14, P. 1-14.

7. GeneRunner http://www.generunner.net/

8. Gromoll J., Simoni M. Genetic complexity of FSH receptor function //Trends in Endocrinology and Metabolism, 2005, Vol. 16, P. 368-373.

9. Hamny H. et al. Polymorphism of follicle stimulating hormone receptor influences the 3D structure and its binding pattern to FSH in Bostaurus // Indian Journal of Animal Research, 2017, Vol. 51, P. 630-634.

10. Hasler J.F. Forty years of embryo transfer in cattle: A review focusing on the journal Theriogenology, the growth of the industry in North America, and personal reminisces // Theriogenology, 2014, Vol. 81, P. 152-169.

11. Houde A. et al. Structure of the bovine follicle-stimulating hormone receptor complementary DNA and expression in bovine tissues // Molecular Reproduction and Development. 1994, Vol. 39, P. 127-35.

12. Joshi A.D., Pajor A.M. Role of conserved prolines in the structure and function of the $\mathrm{Na}+$ /dicarboxylate cotransporter 1, NaDC1 // Biochemistry, 2006, Vol. 45, P. 4231-4239.

13. Kroeze W.K., Sheffler D.J., Roth B.L. G-proteincoupled receptors at a glance // Journal of Cell Science, 2003, Vol. 116, P. 4867-4869.

14. Mapletoft R.J., Hasler J.F. Assisted reproductive technologies in cattle: a review // Revue scientifique et technique, 2005, Vol. 24, P. 393-403.

15. Milazzotto M.P. et al. New molecular variants of hypothalamus-pituitary-gonad axis genes and their association with early puberty phenotype in Bos taurus indicus (Nellore) // Livestock Science, 2008, Vol. 114, P. 274-279.

16. Mossa F. et al. Association between numbers of ovarian follicles in the first follicle wave and superovulatory response in ewes // Animal Reproduction Science, 2007, Vol. 100, P. 391-396.

17. Nicholson H., Tronrud D.E., Becktel W.J., Matthews B.W. Analysis of the effectiveness of proline substitutions and glycine replacements in increasing the stability of phage T4 lysozyme // Biopolymers, 1992, Vol. 32, P. 431-441.

18. Rahal P. et al. Polymorphisms in the bovine folliclestimulating hormone receptor gene // Animal Genetics, 2000, Vol. 31, P. 280-281.

19. Tang K.Q., Yang W.C., Li S.J., Yang L.G. Polymorphisms of the bovine growth differentiation factor 9 gene associated with superovulation performance in Chinese Holstein cows // Genetics and Molecular Research, 2013, Vol. 12, P. 390-399.

20. Yang W.C., Li S.J., Chen L., Yang L.G. FSHR genotype affects estrogen levels but not pregnancy rates in Luxi cattle subjected to embryo transfer // Genetics and Molecular Research, 2014, Vol. 13, P. 1563-1569.

Бабий Анна Владимировна, канд. биол. наук, ФГБНу «Центр экспериментальной эмбриологии и репродуктивных биотехнологий». Россия.

Архипова Анна Леонидовна, младший научный сотрудник, ФГБНУ «Центр экспериментальной эмбриологии и репродуктивных биотехнологий». Россия.

Бурсаков Сергей Алексеевич, канд. биол. наук, старший научный сотрудник, ФГБНУ «Центр экспериментальной эмбриологии и репродуктивных биотехнологий». Россия.

Бригида Артем Владимирович, научный сотрудник, ФГБНУ «Центр экспериментальной эмбриологии и репродуктивных биотехнологий». Росссия.

Климов Евгений Александрович, $\partial-p$ биол. наук, зам. директора по научной работе, ФГБНУ «Центр экспериментальной эмбриологии и репродуктивных биотехнологий». Россия. 
Ковальчук Светлана Николаевна, канд. биол. наук, доцент, врио директора, ФГБНУ «Центр экспериментальной эмбриологии и репродуктивных биотехнологий». Россия.
127422, г. Москва, ул. Костякова, 12, стр. 4. Тел.: (495) 610-21-31.

Ключевые слова: аллельный полиморфизм; FSHR; крупный рогатый скот; ПЦР-ПДРФ.

\title{
EVALUATION OF C337G POLYMORPHISM OF SHR GENE IN THE POPULATION OF BLACK-AND-WHITE HOLSTEINIZED CATTLE
}

Babii Anna Vladimirovna, Candidate of Biological Sciences, Researcher, Center of Experimental Embryology and Reproductive Biotechnologies. Russia.

Arkhipova Anna Leonidovna, Junior Researcher, Center of Experimental Embryology and Reproductive Biotechnologies. Russia.

Bursakov Sergey Alekseevich, Candidate of Biological Sciences, Center of Experimental Embryology and Reproductive Biotechnologies. Russia.

Brigida Artyom Vladimirovich, Researcher, Center of Experimental Embryology and Reproductive Biotechnologies. Russia.

Klimov Evgeniy Aleksandrovich, Doctor of Biological Sciences, Center of Experimental Embryology and Reproductive Biotechnologies. Russia.

Kovalchuk Svetlana Nikolaevna, Candidate of Biological Sciences, Associate Professor, Center of Experimental Embryology and Reproductive Biotechnologies. Russia.

Keywords: allelic polymorphism; FSHR; cattle; PCR-RFLP.
One of the crucial step of the technology of accelerated reproduction of cattle is selection of donor cows, which are the most sensitive to the procedure of hormonal stimulation of ovulation. To date, one of the promising genetic markers of the reproductive status of cattle is the follicle-stimulating hormone receptor (FSHR) gene. Special attention is drawn to SNP C337G (rs43745234), associated with the number of fertilized oocytes and viable embryos. The aim of this work was to evaluate the polymorphism C337G of the FSHR gene in a population of Black-and-White holsteinized cattle. The article presents data on genotyping of 190 Black-and-White holsteinized cows by the allelic variants C337G of FSHR gene (rs43745234) by PCR-RFLP method. Analysis of the results showed that in the studied cattle population $C$ and Gallele frequencies were 0,7 and 0,3 . The frequencies of genotypes $C / C$ and $C / G$ were 474 and 0,453 , respectively. The frequencies of $G / G$ genotype associated with a large number of viable embryos (according to literature data) was only0,074.

DOI

удк 635

\section{ЭФФЕКТИВНОСТЬ ВОЗДЕЛЫВАНИЯ ОЗИМОЙ ПШЕНИЦЫ ПРИ ИСПОЛЬЗОВАНИИ ЛИСТОВЫХ ОБРАБОТОК МИНЕРАЛЬНЫМИ УДОБРЕНИЯМИ И СТИМУЛЯТОРАМИ РОСТА}

\author{
БОНДАРЕНКО Анастасия Николаевна, Прикаспийский научно-исследовательский институт \\ аридного земледелия
}

ТЮТЮМА Андрей Владимирович, Прикаспийский научно-исследовательский институт аридного земледелия

ТютЮМА Никита Андреевич, Волгоградский государственный аграрный университет

ДАНИЛОВ Александр Никифорович, Саратовский государственный аграрный университет имени Н.И. Вавилова

БЕЛОГОЛОВЦЕВ Владимир Петрович, Саратовский государственный аграрный университет имени Н.И. Вавилова

Разработаны элементы агротехнологии возделывания озимой пшеницы, обеспечивающие получение устойчивых урожаев озимой пшенищы на фоне внесения минеральных удобрений в комплексе с внекорневыми (листовыми) обработками стимуляторами роста в условиях «бросовых» полей рисовой оросительной системы (залежъ). Установлено, что максимальная урожайность за три года получена на варианте В (Мастер + Мегафол) - 5,00 m/2a, что на 1,24 m/га (на 33 \%) больше, чем на контрольном варианте. Наибольший уровенъ рентабельности отмечен при обработке озимой пшеницы Лигногуматом (100г/2а) - 215,1 \%, что на 72,2 \% выше контроля.

Введение. Увеличение урожайности и повышение качества зерна озимых культур - главные задачи, стоящие перед сельскохозяйственным производством различных регионов России [1, 2]. Применение минеральных удобрений и ростостимулирующих препаратов улучшает рост и развитие сельскохозяйственных культур и, как следствие, увеличивает продуктивность. Микроудобрения и стимуляторы роста позволяют повысить качество продукции и рентабельность производства [4].

Климатические условия севера Астраханской области в условиях орошения обеспечивают получение довольно высоких урожаев озимой пшеницы. Однако в отдельные годы могут наблюдаться критические периоды, которые сказываются не лучшим образом на процессе вегетации [5, 7-9].

Цель исследований - разработка элементов агротехнологии возделывания озимой пшеницы, обес- печивающих получение устойчивых урожаев озимой пшеницы в условиях «бросовых» полей рисовой оросительной системы (залежь) на светло-каштановой солонцеватой почве севера Астраханской области.

Методика исследований. Исследования проводили в ФГБНУ «Прикаспийский аграрный федеральный научный центр Российской академии наук» в 2015-2017 гг. Почвенный покров опытного участка представлен светло-каштановыми солонцеватыми почвами без наличия пятен солонцов. Эти почвы по гранулометрическому составу преимущественно суглинистые, имеют близкую к нейтральной или слабощелочной реакцию почвенного раствора (pH 7,2-7,6). Содержание гумуса в пахотном слое (0-0,25 м) колеблется в пределах 1,0-1,8 \%, легкогидролизуемого азота - 6-9 мг, подвижного фосфора - 2-4 мг, обменного калия - 50-55 мг на 100 г почвы. Пахотный слой почв характеризуется повышенной плотностью сложе- 